\title{
LITERATURE REVIEW ON STEM CELL TREATMENT \& ORAL SUBMUCOUS FIBROSIS (OSMF)
}

Prathipaty James Sudhakar1, P. B. Kameswararao²

\section{HOW TO CITE THIS ARTICLE:}

Prathipaty James Sudhakar, P. B. Kameswararao. "Literature Review on Stem Cell Treatment \& Oral Submucous Fibrosis (OSMF)". Journal of Evolution of Medical and Dental Sciences 2015; Vol. 4, Issue 63, August 06; Page: 11058-11062, DOI: $10.14260 /$ jemds/2015/1592

ABSTRACT: Stem cell therapy is a part of regenerative medicine that involves the use of undifferentiated cells in order to cure the disease. Stem cell-based therapies are being investigated for the treatment of many conditions, including neurodegenerative conditions such as Parkinson's disease, cardiovascular disease, liver disease, diabetes, autoimmune diseases and for nerve regeneration.(1) In orofacial region these therapies are being used for tooth and periodontal regeneration, temporomandibular joint reconstruction, alveolar bone regeneration. Craniofacial stem cells including dental pulp derived stem cells have the potential to cure a number of diseases.

Present day treatment modalities for oral mucosal lesions like ulcerative lesions, premalignancies and malignancies mainly consist of steroids and antioxidants (which provide only a short term and symptomatic relief) and surgery with or without chemo/radiotherapy (which leave the patient with certain amount of morbidity). Advances in stem cell technology have opened new vistas for treatment of these lesions. Various studies have shown the successful role of stem cell therapies in the treatment of precancerous conditions, oral ulcers, wounds and mucositis.(2) The recent concept of cancer stem cells (CSCs) has directed scientific communities toward a new area of research and possible potential treatment modalities for oral cancer.(3) The present article will discuss the role of stem cell applications in oral mucosal lesions.

KEYWORDS: Review-stem cells-properties-types-applications-role in osmf-results

\section{INTRODUCTION: BASIC CONCEPTS OF STEM CELLS:}

A: Stem Cells \& Types: Stem cells are the precursors of the body tissue. They are defined as immature or undifferentiated cells that are capable of generating daughter cells identical to themselves or of differentiating into diverse cellular phenotypes.(4) There are various types of stem cells. Embryonic stem cells, harvested from fertilized egg or blastocyst, have an extraordinary ability to form many cell types. Adult stem cell, found deep within organs and tissues, spread diffusely throughout and have restricted ability to proliferate. Induced pluripotent stem cells (iPSCs) are adult cells that have been genetically reprogrammed to an embryonic stem cell-like state by being forced to express genes and factors important for maintaining the defining properties of embryonic stem cells.

They express stem cell markers also and are capable of generating cells characteristic of all three germ layers. iPSCs may prove to be useful tools for drug development and modeling of diseases and in transplantation medicine.(5,6) The stem cells are also divided into totipotent stem cells (e.g., fertilized egg cell or zygote), that can generate all cell and tissue types present in an organism; Pluripotent stem cells (like embryonic stem cells) can generate the majority of cell and tissue types present in an organism; multipotent stem cells (like mesenchymal stem cells [MSC]) can generate a limited number of cell and tissue types, usually dependent on their germ layer of origin.(6) 


\section{REVIEW ARTICLE}

B: Properties: The main properties of stem cell, which make it different from any other specialized cells in the body are: Self-renewal, that is the ability to go through numerous cycles of cell division while maintaining their undifferentiated state; differentiation, that is the ability to differentiate into a specialized cell type and the ability to grow in vitro, in a laboratory, under a given environment.

C: Extraction of Stem Cells: Stem cells can be derived from the following sources like embryonic stem cells sources, ${ }^{(7)}$ and adult stem cells sources. The tissue samples containing stem cells are placed under specific conditions in laboratories/stem cell banks. The extraction of these stem cells is possible due to unique receptors like 0ct4, TRA-1-60 (called as stem cell markers) present on the stem cell surface.(8) The extracted stem cells are grown on an appropriate scaffold made of biomaterials (like polyglycolic acid, polytetrafluoroethylene), fibrin sealant and certain growth factors, which act as temporary matrix during the regeneration of tissue. $(9,10)$

Application in Orofacial Region: Mesenchymal stem cells derived from dental and nondental sources have been effectively used for regeneration in maxillofacial region like regeneration of tooth, pulp, periodontal ligament, production of enamel and dentin, regeneration of salivary gland, repair of cleft lip and palate and craniofacial regeneration.(11,12,13) However, the use of stem cell treatment for oral mucosal lesions is a new concept, which needs to be reviewed to promote the research further in the area. Mesenchymal stromal/stem cells (MSCs) based therapies hold great promise for prophylactic treatment of vocal fold scar or atrophy. Preclinical in vitro and in vivo studies have shown no adverse risks with MSCs transplantation into the vocal fold, $(14,15,16)$ Interestingly, a newly developed bioreactor capable of mimicking vocal fold vibration showed that BM MSCs do not increase their production of ECM genes after eight hours of $200 \mathrm{~Hz}$ vibration.(17) Therefore, MSCs transplantation into the vocal fold should be able to withstand short-periods of vibration without modulating their expression of fibrous proteins. However, further risk assessments are needed to determine the differentiation and proliferation capacity of MSCs under long-term vibratory conditions.

Oral Submucosal Fibrosis: Oral Sub-Mucous Fibrosis (OSMF) is a chronic disease of insidious onset featuring the deposition of fibrosis tissues in the sub-mucosal layer of the pharynx, palate, fauces, cheek, lips, pharynx and esophagus, underlying muscles of mastication are also affected (Mokal et al. 2005) and it restricts the mouth opening. OSMF is associated with both significant morbidity and an increased risk of malignancy. Various agents like Areca nut, gutkha, spices etc., are known to cause insult to oral mucosa by increasing cytokine production and release of reactive oxygen species; which in turn results in increased synthesis of collagen, decreased collagen breakdown, compromised vascularity and increased tissue oxidative stress, ultimately resulting in clinical OSMF.(18)

Various medicinal, as well as surgical treatment modalities, have been tried to intervene the disease process at different levels, but with limited success. Stem cell-based therapy is evolving as a promising new approach in this direction.

Stem cell therapy is primarily aimed at neoangiogenesis by releasing cytokines and growth factors (Paracrine effect).

This may result in increased free radical scavenging by antioxidants (either naturally occurring or extraneous) 


\section{REVIEW ARTICLE}

Neoangiogenesis may also facilitate the removal of senescent cells from the lesions by supplying more number of scavenging defense cells and reversal of hypoxia in the diseased tissue.

Stem cell therapy may help to stimulate resident tissue stem cells to transform into new fibroblasts, which may help in the removal of disintegrated biochemically and morphologically altered collagen fibers. $(19,20)$

Sankaranarayanan et al. have demonstrated in a 43yrs old male patient suffering from OSMF for the past 10yrs who was treated 3yrs before with cortisone injection and by other adjunctive medical management with no improvement was treated by this method. He had the complications such as severe burning sensation, difficulty in swallowing, severe blanching, restricted mouth opening of $30 \mathrm{~mm}$ and xerostomia. They did pre-injection biopsy, to confirm the pathology and also to rule out carcinoma. They took $40 \mathrm{ml}$ of Bone Marrow, aspirated from posterior iliac crest, transported in Acid Citrate Dextrose and processed for mononuclear cells (MNC) by Ficoll density gradient centrifugation, following the cGMP protocols. The $4 \mathrm{~mL}$ of MNC concentrate containing 294 million was injected intra orally at various sites in the affected area under local anesthesia.

They observed the patient did not show any improvement till 4 weeks after the stem cell injection. From then, he as gradually started showing relief from burning sensation, increased salivary secretion and a $4 \mathrm{~mm}$ increase in the mouth opening. H\&E stain comparison of pre and post injection biopsy showed signs of angiogenesis with increase in number of capillaries, return of wavy pattern of collagen fibres with less inflammatory cell infiltration indicating the degranulation of the fibrous tissue and loosely organised connective tissue, all indicating a resumption towards a normal histology. $(19,20)$

CONCLUSION: Remedies in the medical field have always resulted from human inquisitiveness to know the nature and duplicate it. The conservative treatment of life-threatening and disfiguring defects and diseases is becoming the treatment of choice. The ability to treat currently incurable diseases has become a reality with the evolution of stem cell therapy. Though certain studies have confirmed the effectiveness of stem cell therapy in oral mucosal disorders like OSMF, for diseases like oral ulcers and mucositis, the research is mainly confined to animal models and more human research trials are needed to ascertain the role of stem cells in their management. There lies the need of extensive research by team of professionals including stem cell biologists, molecular biologists, geneticists, biomaterial scientists, mechanical engineers and clinicians with knowledge of oral and maxillofacial disorders to make stem cell therapy a promising tool in such conditions. The evolution of more methods of stem cell therapy in the future will give more simple, definitive and effective treatment of most of the oral mucosal diseases.

\section{REFERENCES:}

Main: G. N. Suma, Madhu Pruthi Arora, and Manisha Lakhanpal J Pharm Bioallied Sci. 2015 Jan-Mar; 7(1): 2-8. doi: 10.4103/0975-7406.149809.

1. Kim RH, Mehrazarin S, Kang MK. Therapeutic potential of mesenchymal stem cells for oral and systemic diseases. Dent Clin North Am. 2012; 56: 651-75. [PMC free article] [PubMed].

2. Devi P, Thimmarasa VB, Jayadev S, Mehrotra V, Arora P. Stem cells: Treading the unexplored path. J Oral Sign. 2010; 2: 41-453.

3. Sagar J, Chaib B, Sales K, Winslet M, Seifalian A. Role of stem cells in cancer therapy and cancer stem cells: A review. Cancer Cell Int. 2007; 7: 9. [PMC free article] [PubMed]. 
4. Robey PG. Stem cells near the century mark. J Clin Invest. 2000; 105: 1489-91. [PMC free article][PubMed].

5. Okita K.Curr Opin Organ Transplant. 2011 Feb; 16(1): 96-100. doi: 10.1097/MOT.0b013e32834252a2. Review. PMID: 21150614

6. Mochiduki Y, Okita K. Biotechnol J. 2012 Jun; 7(6): 789-97. doi: 10.1002/biot.201100356. E pub 2012 Feb 29. Review. PMID: 22378737

7. Schuldiner M, Yanuka O, Itskovitz-Eldor J, Melton DA, Benvenisty N. From the cover: effects of eight growth factors on the differentiation of cells derived from human embryonic stem cells. Proc Natl Acad Sci U S A. 2000; 97: 11307-11312.

8. Nagano K, Yoshida Y, Isobe T. Cell surface biomarkers of embryonic stem cells. Proteomics.2008; 8: 4025-35. [PubMed].

9. Horst OV, Chavez MG, Jheon AH, Desai T, Klein OD. Stem cell and biomaterials research in dental tissue engineering and regeneration. Dent Clin North Am. 2012; 56: 495-520. [PMC free article] [PubMed].

10. Gasparotto VP, Landim-Alvarenga FC, Oliveira AL, Simões GF, Lima-Neto JF, Barraviera B, et al. A new fibrin sealant as a three-dimensional scaffold candidate for mesenchymal stem cells. Stem Cell Res Ther.2014; 5: 78. [PMC free article] [PubMed].

11. Wu SM, Chiu HC, Chin YT, Lin HY, Chiang CY, Tu HP, et al. Effects of enamel matrix derivative on the proliferation and osteogenic differentiation of human gingival mesenchymal stem cells. Stem Cell Res Ther. 2014; 5: 52. [PMC free article] [PubMed].

12. Janebodin K, Reyes M. Neural crest-derived dental pulp stem cells function as ectomesenchyme to support salivary gland tissue formation. Dentistry S13: 001. doi: 10.4172/2161-1122S13-001.

13. 13.Bueno DF, Sunaga DY, Kobayashi GS, Aguena M, Raposo-Amaral CE, Masotti C, et al. Human stem cell cultures from cleft lip/palate patients show enrichment of transcripts involved in extracellular matrix modeling by comparison to controls. Stem Cell Rev. 2011; 7: 446-57. [PMC free article] [PubMed].

14. Johnson BQ, Fox $\mathrm{R}$, Chen $\mathrm{X}$, Thibeault $\mathrm{S}$. Tissue regeneration of the vocal fold using bone marrow mesenchymal stem cells and synthetic extracellular matrix injections in rats. Laryngoscope.2010; 120: 537-545. [PMC free article] [PubMed].

15. Duflo S, Thibeault SL, Li W, Shu XZ, Prestwich G. Effect of a synthetic extracellular matrix on vocal fold lamina propria gene expression in early wound healing. Tissue Eng. 2006; 12: 32013207. [PubMed].

16. Chen X, Thibeault SL. Biocompatibility of a synthetic extracellular matrix on immortalized vocal fold fibroblasts in 3-D culture. Acta Biomater. 2010; 6: 2940-2948. [PMC free article][PubMed].

17. Gaston J, Quinchia Rios B, Bartlett R, Berchtold C, Thibeault SL. The response of vocal fold fibroblasts and mesenchymal stromal cells to vibration. PLoS One. 2012; 7: e30965. [PMC free article][PubMed].

18. Sudarshan R, Annigeri R, Vijayabala G. Pathogenesis of oral submucous fibrosis: The past and current concepts. Int J Oral Maxillofac Pathol. 2012; 3: 27-36.

19. Sankaranarayanan S, Ramachandran C, Padmanabhan J, Manjunath S, Baskar S, Senthil Kumar $\mathrm{R}$, et al. Novel approach in the management of an oral premalignant condition - A case report. J Stem Cells Regen Med. 2007; 3: 21. [PubMed]. 


\section{REVIEW ARTICLE}

20. Sankaranarayanan S, Kailasam S, Elangovan S, Ravi VR, Sarkar S. Autologous bone marrow concentrate (Mononuclear Stem Cell) therapy in the treatment of oral submucous fibrosis. J Indian Acad Oral Med Radiol. 2013; 25: 1-4.

\section{AUTHORS:}

1. Prathipaty James Sudhakar

2. P. B. Kameswararao

\section{PARTICULARS OF CONTRIBUTORS:}

1. Consultant ENT Surgeon, Visakhapatnam, Andhra Pradesh.

2. Associate Professor, Department of ENT, Great Eastern Medical School (GEMS), Srikakulam, Andhra Pradesh.

FINANCIAL OR OTHER COMPETING INTERESTS: None
NAME ADDRESS EMAIL ID OF THE CORRESPONDING AUTHOR:

Dr. Prathipaty James Sudhakar 1-68-22/1,

Sector 2, M. V. P. Colony,

Visakhapatnam-530017,

Andhra Pradesh.

E-mail: docpjs@gmail.com

Date of Submission: 13/06/2015.

Date of Peer Review: 15/06/2015.

Date of Acceptance: 13/07/2015.

Date of Publishing: 06/08/2015. 